\title{
Should Clinicians Use Chloroquine or Hydroxychloroquine Alone or In Combination With Azithromycin for the Prophylaxis or Treatment of COVID-19? Living Practice Points From the American College of Physicians (Version 1)
}

\author{
Amir Qaseem, MD, PhD, MHA; Jennifer Yost, RN, PhD; Itziar Etxeandia-Ikobaltzeta, PharmD, PhD; Matthew C. Miller, MD; \\ George M. Abraham, MD, MPH; Adam Jacob Obley, MD; Mary Ann Forciea, MD; Janet A. Jokela, MD, MPH; and \\ Linda L. Humphrey, MD, MPH; for the Scientific Medical Policy Committee of the American College of Physicians*
}

\section{Key Question 1}

Should Clinicians Use Chloroquine or Hydroxychloroquine Alone or in Combination With Azithromycin for Prophylaxis Against COVID-19?

\section{Key Question 2}

Should Clinicians Use Chloroquine or Hydroxychloroquine Alone or in Combination With Azithromycin for Treatment of COVID-19?

\section{BACKGROUND}

Using chloroquine or hydroxychloroquine, with or without azithromycin, to prevent coronavirus disease (COVID-19) after infection with novel coronavirus (SARS-CoV-2) or to treat COVID-19 began to receive attention following preliminary reports from in vitro (1) and human (2) studies. While multiple studies are planned or under way $(3,4)$, it is imperative to continually synthesize the results from the best available evidence to inform point-of-care decisions about the use of chloroquine or hydroxychloroquine. These practice points are based on a rapid and living systematic evidence review conducted by the University of Connecticut Health Outcomes, Policy, and Evidence Synthesis Group and will be updated as new evidence becomes available. The practice points development and update methods are included in the appendix, available at Annals.org. This version of the practice points, based on an evidence review conducted on 17 April 2020, was approved by the American College of Physicians Board of Regents on 4 May 2020 and submitted to Annals of Internal Medicine on 6 May 2020.

\section{Practice Points}

The efficacy of chloroquine or hydroxychloroquine alone or in combination with azithromycin to prevent COVID-19 after infection with SARS-CoV-2 or to treat patients with COVID-19 is not established and future clinical trials are needed to answer these questions. There are known harms of these medications when used to treat other diseases $(5,6)$. Current evidence about efficacy and harms for use in the context of COVID-19 is sparse, conflicting, and from low quality studies, increasing the uncertainty and lowering our confidence in the conclusions of these studies when assessing the benefits or understanding the balance when compared with harms. These interim practice points are based on best available evidence. We will maintain these practice points as a living guidance document, updated as new evidence becomes available.

- Do not use chloroquine or hydroxychloroquine alone or in combination with azithromycin as prophylaxis against COVID-19 due to known harms and no available evidence of benefits in the general population.

- Do not use chloroquine or hydroxychloroquine alone or in combination with azithromycin as a treatment of patients with COVID-19 due to known harms and no available evidence of benefits in patients with COVID-19.

- In light of known harms and very uncertain evidence of benefit in patients with COVID-19, using shared and informed decision making with patients (and their families), clinicians may treat hospitalized COVID-19-positive patients with chloroquine or hydroxychloroquine alone or in combination with azithromycin in the context of a clinical trial.

This article was published at Annals.org on 13 May 2020

* This paper, written by Amir Qaseem, MD, PhD, MHA; Jennifer Yost, RN, PhD; Itziar Etxeandia-lkobaltzeta, PharmD, PhD; Matthew C. Miller, MD; George M. Abraham, MD, MPH; Adam J. Obley, MD; Mary Ann Forciea, MD; Janet A. Jokela, MD, MPH; and Linda L. Humphrey, MD, MPH, was developed for the Scientific Medical Policy Committee of the American College of Physicians. Individuals who authored this work and served on the Scientific Medical Policy Committee from initiation of the project until its approval were Linda L. Humphrey, MD, MPH (Chair); Robert M. Centor, MD (Vice Chair); Elie A. Akl, MD, MPH, PhD; Rebecca Andrews, MS, MD; Thomas A. Bledsoe, MD; Mary Ann Forciea, MD; Ray Haemet; Janet A. Jokela, MD, MPH; Devan L. Kansagara, MD, MCR; Maura Marcucci, MD, MSc; Matthew C. Miller, MD; and Adam Jacob Obley, MD. Approved by the ACP Board of Regents on 4 May 2020.

† Nonphysician public representative. 
Should chloroquine or hydroxychloroquine alone or in combination with azithromycin be used as prophylaxis against COVID19 in the general population?

\begin{tabular}{lll}
\hline Interventions & Use? & Rationale \\
\hline Chloroquine & NO & No available evidence \\
Chloroquine + Azithromycin & NO & No available evidence \\
Hydroxychloroquine & NO & No available evidence \\
Hydroxychloroquine + Azithromycin & NO & No available evidence \\
\hline
\end{tabular}

Should chloroquine or hydroxychloroquine alone or in combination with azithromycin be used for treatment of patients with COVID-19?

\begin{tabular}{lll}
\hline Interventions & Use? & Rationale \\
\hline Chloroquine & $\mathrm{NO}^{*}$ & $\begin{array}{c}\text { No available evidence in COVID-19-positive } \\
\text { patients } \\
\text { No available evidence in COVID-19-positive } \\
\text { patients } \\
\text { Hydroxychloroquine }\end{array}$ \\
$\begin{array}{l}\text { NO* } \\
\text { Insufficient evidence about benefits } \\
\text { and harms } \\
\text { Insufficient evidence about benefits } \\
\text { and harms }\end{array}$ \\
\hline
\end{tabular}

* In light of known harms and very uncertain evidence of benefit in patients with COVID-19, using shared and informed decisionmaking with patients (and their families), clinicians may treat hospitalized COVID-19-positive patients with chloroquine or hydroxychloroquine alone or in combination with azithromycin in the context of a clinical trial.

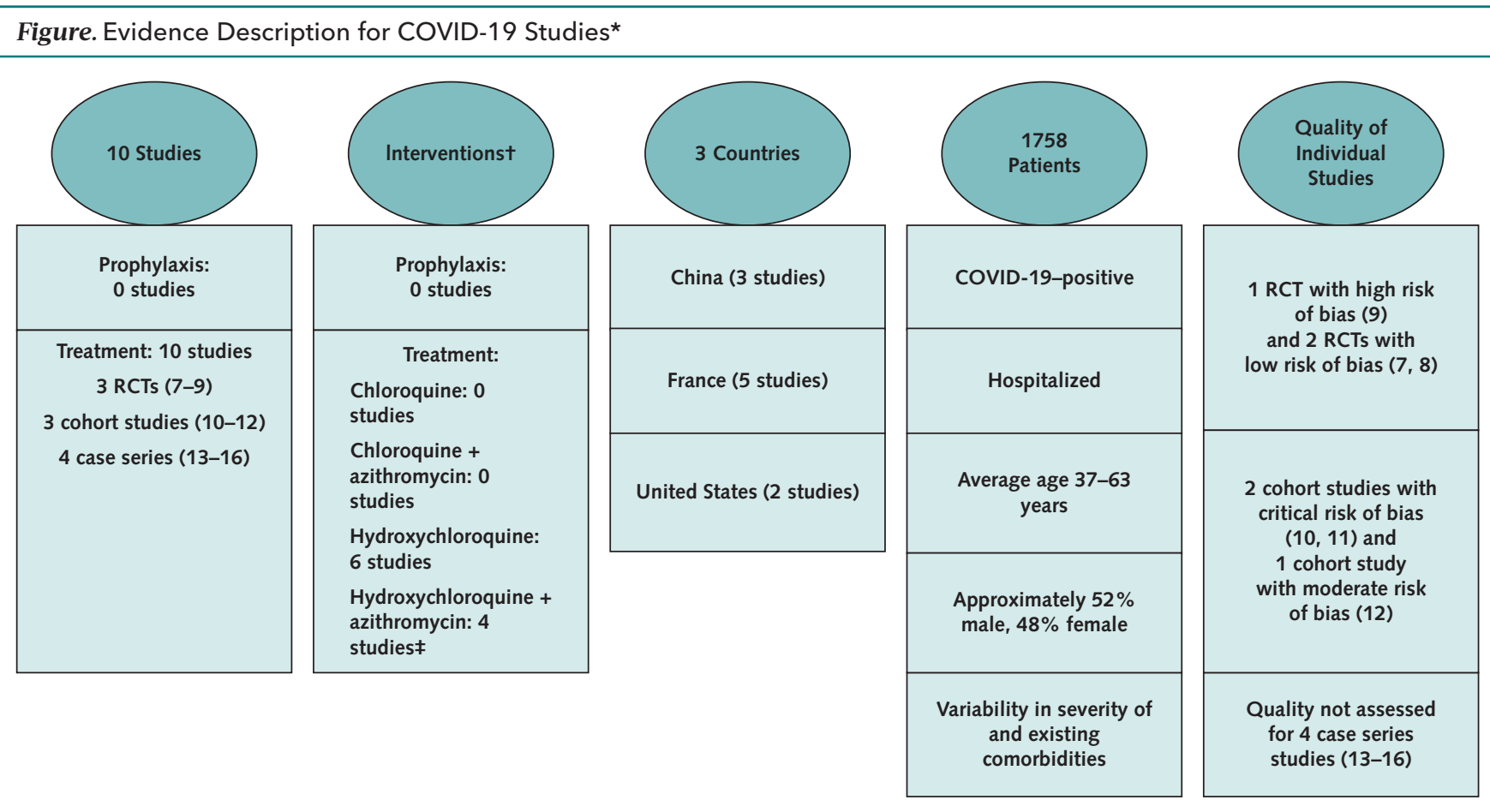

COVID-19 = coronavirus disease 2019; RCT = randomized controlled trial.

* Evidence search was conducted by the University of Connecticut Health Outcomes, Policy, and Evidence Synthesis Group. Current search for evidence, completed on 17 April 2020, aimed to identify all studies about the use of chloroquine or hydroxychloroquine alone or in combination for prophylaxis or treatment of patients with COVID-19. (See Supplement, available at Annals.org.) † The use and extent of parallel treatment interventions was difficult to determine. For example, in some studies, it was documented that patients received parallel interventions, whereas in other studies there was insufficient information to determine if patients did or did not receive parallel interventions.

$\ddagger$ In 2 cohort studies $(11,12)$, the administration of azithromycin was not randomized, precluding judgment of efficacy. 
Evidence Summary: What Information Does the Evidence Provide?

\begin{tabular}{l}
\hline \multicolumn{1}{c}{ Prophylaxis } \\
\hline Evidence for Potential Benefits \\
\hline No studies identified
\end{tabular}

\section{Evidence for Potential Harms}

No studies identified

\section{Treatment}

\section{Evidence for Potential Benefits*}

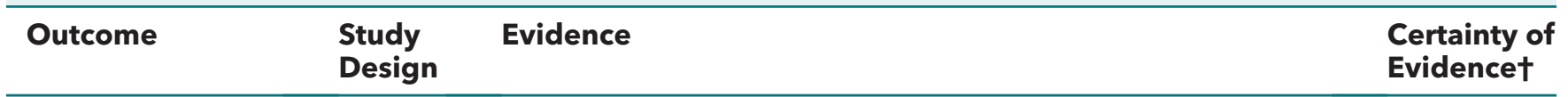

\section{Hydroxychloroquine alone for treatment of COVID-19}

Conversion of 2 RCTs
SARS-CoV-2 test
result from
positive to
negative

negative

1 OBS
$\begin{aligned} & \text { Pulmonary } \\ & \text { radiologic } \\ & \text { assessment }\end{aligned}$
2 RCTs
$\begin{aligned} & \text { Resolution of fever, } \\ & \text { respiratory } \\ & \text { symptoms, and } \\ & \text { oxygenation }\end{aligned}$
$\begin{aligned} & \text { Resolution of fever } \\ & \text { ReT }\end{aligned}$

$\begin{array}{ll}\begin{array}{l}\text { Resolution of } \\ \text { cough }\end{array} & 1 \mathrm{RCT} \\ \begin{array}{l}\text { Progression to } \\ \text { severe disease }\end{array} & 2 \mathrm{RCTs} \\ \text { All-cause mortality } & 1 \mathrm{RCT} \\ & 2 \mathrm{OBS}\end{array}$

The evidence is very uncertain about the effect of hydroxychloroquine alone compared with standard treatment on day 7 (86.7\% vs. $93.3 \%)$ or day 14 (100\% vs. $100 \%)$ via throat swab, sputum, or lower respiratory tract secretion and the time to negative results was 1 to 9 days for patients treated with hydroxychloroquine alone and 1 to 4 days for those receiving standard treatment in 1 RCT (7) and hydroxychloroquine alone compared standard treatment up to day 23 (85.4\% vs. $81.3 \%$ ) via upper and/or lower tract specimens or the time to negative results ( 8 days vs. 7 days) in another RCT (9).

The evidence is very uncertain about the effect of hydroxychloroquine alone compared with standard treatment on the conversion to negative on day 3 (50\% vs. $6 \%$ ), day 4 (60\% vs. $25 \%)$, day 5 (65\% vs. $19 \%)$, and day 6 (70\% vs. $13 \%)$ via nasopharyngeal PCR in 1 cohort study (11).

The evidence is very uncertain about the effect of hydroxychloroquine alone compared with standard treatment on the progression or exacerbation of pulmonary lesions on CT scan in 2 RCTs (33.3\% vs. 46.7\% [7] and 6.5\% vs. $29 \%$ [8]) and radiologic improvement of pneumonia ( $80.6 \%$ vs. $54.8 \%$ ) in 1 RCT (8).

The evidence is very uncertain about the effect of hydroxychloroquine alone (50\%) compared with standard treatment $(43.6 \%)$ in 1 RCT (9).

The evidence is very uncertain about the effect of hydroxychloroquine alone compared with standard treatment in 2 RCTs; median, 1 day vs. 1 day in 1 RCT (7), and mean, 2.2 days vs. 3.2 days in another RCT (8).

The evidence is very uncertain about the effect of hydroxychloroquine alone compared with standard treatment (mean 2.0 days vs. 3.1 days) in 1 RCT (8).

The evidence is very uncertain about the effect of hydroxychloroquine alone compared with standard treatment in 2 RCTs; $6.7 \%$ vs. $0 \%$ (7) and $0 \%$ vs. $12.9 \%$ (8).

The evidence is very uncertain about the effect of hydroxychloroquine alone compared with standard treatment $(0 \%$ vs. $0 \%$ ) in $1 \mathrm{RCT}(7)$.

The evidence is very uncertain about the effect of hydroxychloroquine alone compared with standard treatment in 2 cohort studies; $12.9 \%$ vs. $3.13 \%$ (10) and $2.8 \%$ vs. $4.6 \%$ (12).
Insufficient

Insufficient

(n)

$$
\text { Insufficient }
$$

Insufficient

Insufficient

Insufficient

Insufficient 


\section{Treatment}

\begin{tabular}{|c|c|c|c|}
\hline \multicolumn{4}{|c|}{$\checkmark$ Evidence for Potential Benefits* } \\
\hline Outcome & $\begin{array}{l}\text { Study } \\
\text { Design }\end{array}$ & Evidence & $\begin{array}{l}\text { Certainty of } \\
\text { Evidencet }\end{array}$ \\
\hline $\begin{array}{l}\text { Respiratory } \\
\text { support }\end{array}$ & $1 \mathrm{OBS}$ & $\begin{array}{l}\text { The evidence is very uncertain about the effect hydroxychloro- } \\
\text { quine alone compared with standard treatment on the need at } \\
5 \text { days ( } 0.63 \pm 0.79 \text { vs. } 0.16 \pm 0.64 \text { points) in } 1 \text { cohort study } \\
\text { (10). }\end{array}$ & Insufficient \\
\hline $\begin{array}{l}\text { Development of } \\
\text { acute respiratory } \\
\text { distress syndrome }\end{array}$ & $1 \mathrm{OBS}$ & $\begin{array}{l}\text { The evidence is very uncertain about the effect of hydroxy- } \\
\text { chloroquine alone compared with standard treatment } \\
\text { (27.7\% vs. } 24.1 \%) \text { in } 1 \text { cohort study (12). }\end{array}$ & Insufficient \\
\hline Clinical worsening & $1 \mathrm{OBS}$ & $\begin{array}{l}\text { The evidence is very uncertain about the effect hydroxychloro- } \\
\text { quine alone compared with standard treatment ( } 20.5 \% \text { vs. } \\
22.1 \% \text { ) in } 1 \text { cohort study on transfer to the ICU within } 7 \text { days } \\
\text { and/or death from any cause (12). }\end{array}$ & Insufficient \\
\hline
\end{tabular}

Evidence for Potential Harms

\begin{tabular}{|c|c|c|c|}
\hline Outcome & $\begin{array}{l}\text { Study } \\
\text { Design }\end{array}$ & Evidence & $\begin{array}{l}\text { Certainty of } \\
\text { Evidencet }\end{array}$ \\
\hline \multicolumn{4}{|c|}{ Hydroxychloroquine alone for treatment of COVID-19 } \\
\hline $\begin{array}{l}\text { Severe adverse } \\
\text { events }\end{array}$ & 2 RCTs & $\begin{array}{l}\text { The evidence is very uncertain about the effect of hydroxy- } \\
\text { chloroquine alone compared with standard treatment in } 2 \\
\text { RCTs; } 0 \% \text { vs. } 0 \% \text { (8) and } 2.9 \% \text { vs. } 0 \% \text { (9). }\end{array}$ & Insufficient \\
\hline Any adverse event & 3 RCTs & $\begin{array}{l}\text { The evidence is very uncertain about the effect of hydroxy- } \\
\text { chloroquine alone compared with standard treatment on } \\
\text { adverse effects in } 3 \text { RCTs; } 26.7 \% \text { vs. } 20 \% \text { (7), } 6.5 \% \text { vs. } 0 \% \text { (8), } \\
\text { and } 30 \% \text { vs. } 8.8 \% \text { (9). }\end{array}$ & Insufficient \\
\hline $\begin{array}{l}\text { Prolonged QTC } \\
\text { interval }\end{array}$ & $1 \mathrm{OBS}$ & $\begin{array}{l}\text { The evidence is very uncertain about the effect of hydroxy- } \\
\text { chloroquine alone compared with standard treatment ( } 8.3 \% \\
\text { vs. } 0 \% \text { ) in } 1 \text { cohort study (12). }\end{array}$ & Insufficient \\
\hline Diarrhea & 2 RCTs & $\begin{array}{l}\text { The evidence is very uncertain about the effect of hydroxy- } \\
\text { chloroquine alone compared with standard treatment; } \\
13.3 \% \text { vs. } 0 \% \text { (7) and } 10 \% \text { vs. } 0 \%(9) \text {. }\end{array}$ & Insufficient \\
\hline $\begin{array}{l}\text { Abnormal liver } \\
\text { function }\end{array}$ & $1 \mathrm{RCT}$ & $\begin{array}{l}\text { The evidence is very uncertain about the effect of hydroxy- } \\
\text { chloroquine alone (6.7\%) compared with standard treatment } \\
(6.7 \%) \text { in } 1 \text { RCT (7). }\end{array}$ & Insufficient \\
\hline Rash & $1 \mathrm{RCT}$ & $\begin{array}{l}\text { The evidence is very uncertain about the effect of hydroxy- } \\
\text { chloroquine alone (3.2\%) compared with standard treatment } \\
(0 \%) \text { in } 1 \mathrm{RCT}(8) \text {. }\end{array}$ & Insufficient \\
\hline Headache & $1 \mathrm{RCT}$ & $\begin{array}{l}\text { The evidence is very uncertain about the effect of hydroxy- } \\
\text { chloroquine alone (3.2\%) compared with standard treatment } \\
(0 \%) \text { in } 1 \mathrm{RCT}(8) \text {. }\end{array}$ & Insufficient \\
\hline Anemia & $1 \mathrm{RCT}$ & $\begin{array}{l}\text { The evidence is very uncertain about the effect of hydroxy- } \\
\text { chloroquine alone (0\%) compared with standard treatment } \\
(6.7 \%) \text { in } 1 \mathrm{RCT}(7) \text {. }\end{array}$ & Insufficient \\
\hline $\begin{array}{l}\text { Elevated serum } \\
\text { creatinine }\end{array}$ & $1 \mathrm{RCT}$ & $\begin{array}{l}\text { The evidence is very uncertain about the effect of hydroxy- } \\
\text { chloroquine alone (0\%) compared with standard treatment } \\
(6.7 \%) \text { in } 1 \mathrm{RCT}(7) \text {. }\end{array}$ & Insufficient \\
\hline \multicolumn{4}{|c|}{ Hydroxychloroquine in combination with azithromycin for treatment of COVID-19 } \\
\hline Diarrhea & $1 \mathrm{OBS}$ & $\begin{array}{l}\text { The evidence is very uncertain about the effect of hydroxy- } \\
\text { chloroquine in combination with azithromycin in } 1 \text { case se- } \\
\text { ries study (14); } 5.0 \% \text { patients experienced diarrhea. }\end{array}$ & Insufficient \\
\hline Any adverse event & $1 \mathrm{OBS}$ & $\begin{array}{l}\text { The evidence is very uncertain about the effect of hydroxy- } \\
\text { chloroquine in combination with azithromycin in } 1 \text { case }\end{array}$ & Insufficient \\
\hline
\end{tabular}




\section{Treatment}

$X$ Evidence for Potential Harms

\begin{tabular}{llll}
\hline Outcome & $\begin{array}{l}\text { Study } \\
\text { Design }\end{array}$ & Evidence & $\begin{array}{l}\text { Certainty of } \\
\text { Evidencet }\end{array}$ \\
\hline
\end{tabular}

series study; $8.7 \%$ of patients treated with hydroxychloro-

quine alone experienced adverse effects (14).

Prolonged OTC 3 OBS

The evidence is very uncertain about the effect of hydroxy-

Insufficient

chloroquine in combination with azithromycin. In 2 case series studies, 9\% (15) and $11 \%$ (13) of patients showed a prolonged QTc. The QTc interval significantly increased (435 $\pm 24 \mathrm{~ms}$ at baseline to a maximal value of $463 \pm 32 \mathrm{~ms}$ ) in 1 case series study (13); however, a prolonged QTc interval was not reported for any patients in another case series study (16).

\section{? Evidence Gaps for COVID-19}

- Efficacy and safety of chloroquine used alone or in combination with azithromycin for prophylaxis or treatment of COVID-19 [no evidence].

- Efficacy and safety of hydroxychloroquine used alone or in combination with azithromycin for prophylaxis of COVID-19 infection [no evidence].

- Efficacy and safety of hydroxychloroquine used alone or in combination with azithromycin for treatment of patients with COVID-19 with varying severity of disease [insufficient evidence].

- Evaluation of important clinical outcomes including survival, respiratory failure, duration of mechanical ventilation, and use of ECMO [no evidence].

\section{Clinical Considerations}

- The use and extent of parallel treatment interventions, in addition to hydroxychloroquine alone or in combination with azithromycin, is difficult to determine.

- Known harms of chloroquine in patients without COVID-19 include (but not limited to): cardiovascular (cardiomyopathy, ECG changes), hematologic (aplastic anemia, thrombocytopenia), nervous system (seizures, psychosis, extrapyramidal disorders), ophthalmic macular degeneration) (5).

- Known harms of hydroxychloroquine in patients without COVID-19 include (but not limited to): cardiovascular (cardiomyopathy, cardiac failure, ventricular arrhythmias, torsade de pointes), endocrine (hypoglycemia), hematologic (aplastic anemia, thrombocytopenia), nervous system (seizures, psychosis, extrapyramidal disorders), ophthalmic macular degeneration) (6).

- Shared and informed decision making with a patient (and/or families) should include a discussion of potential harms of chloroquine and hydroxychloroquine and lack of known benefits in patients with COVID-19.

- In the evidence reviewed, hydroxychloroquine doses did not exceed $600 \mathrm{mg}$ daily for 5 to 10 days.

- Chloroquine and hydroxychloroquine are used to manage other major ailments, such as rheumatic diseases, with a known benefit and are in short supply in the United States.

- Inappropriate and overuse of antibiotics (e.g., azithromycin) is an important contributor to the antibiotic resistance, an immediate public health threat (17).

$\mathrm{CT}$ = computed tomography; ECG = electrocardiography; ECMO = extracorporeal membrane oxygenation; ICU = intensive care unit; $\mathrm{OBS}=$ observational study; PCR = polmerase chain reaction; $\mathrm{RCT}$ = randomized controlled trial.

Evidence search conducted by the University of Connecticut Health Outcomes, Policy, and Evidence Synthesis Group.

* Efficacy cannot be evaluated in case-series studies $(16,18)$.

† Certainty: insufficient, when confidence is inadequate to assess the likelihood of benefit (benefit minus harm) of an intervention or its impact on a health outcome; low, confidence in the effect is limited as the true effect may be substantially different from the estimated effect; moderate, confidence in the effect is moderate as the true effect is likely close to the estimated effect, but there is a sizable possibility that it is substantially different; high, confident that the true effect is close to the estimated effect.

From American College of Physicians, Philadelphia, Pennsylvania (A.Q., I.E.-I.); American College of Physicians, Philadelphia, and Villanova University, Villanova, Pennsylvania (J.Y.); Penn Medicine, Philadelphia, Pennsylvania (M.C.M.); University of Massachusetts Medical School/Saint Vincent Hospital, Worcester,
Massachusetts (G.M.A.); Portland Veterans Affairs Medical Center and Oregon Health \& Science University, Portland, Oregon (A.J.O, L.L.H.); University of Pennsylvania Health System, Philadelphia, Pennsylvania (M.A.F.); and University of Illinois at Urbana-Champaign, Champaign, Illinois (J.A.J.). 
Note: The Practice Points are developed by the Scientific Medical Policy Committee of the American College of Physicians. The Practice Points are "guides" only and may not apply to all patients and all clinical situations. All Practice Points are considered automatically withdrawn or invalid 5 years after publication, or once an update has been issued.

Acknowledgment: The Scientific Medical Policy Committee thanks Adrian V. Hernandez, MD, PhD; Yuani M. Roman, MD, $\mathrm{MPH}$; Vinay Pasupuleti, MD, MS, PhD; Joshuan J. Barboza, MSc; and C. Michael White, PharmD, of the University of Connecticut Health Outcomes, Policy, and Evidence Synthesis Group for conducting the rapid evidence review that informed the development of these Practice Points.

Financial Support: Financial support for the development of the Practice Points comes exclusively from the ACP operating budget.

Disclosures: All financial and intellectual disclosures of interest were declared and potential conflicts were discussed and managed. A record of disclosures of interest and management of conflicts of is kept for each Scientific Medical Policy Committee meeting and conference call and can be viewed at https://www.acponline.org/about-acp/who-we-are/leadership/ boards-committees-councils/scientific-medical-policy-committee/ disclosure-of-interests-and-conflict-of-interest-managementsummary-for-scientific-medical-policy. Disclosures can also be viewed at www.acponline.org/authors/icmje/ConflictOflnterest Forms.do?msNum=M20-1998.

Corresponding Author: Amir Qaseem, MD, PhD, MHA, American College of Physicians, 190. N Independence Mall West, Philadelphia, PA 19106; e-mail, aqaseem@acponline.org.

Current author addresses and author contributions are available at Annals.org.

Correction: This article was corrected on 26 May 2020 to correct several errors, which are detailed in the Correction (www.annals.org/doi/10.7326/L20-0684).

Ann Intern Med. 2020. doi: 10.7326/M20-1998

\section{References}

1. Wang $M$, Cao $R$, Zhang $L$, et al. Remdesivir and chloroquine effectively inhibit the recently emerged novel coronavirus (2019$\mathrm{nCoV}$ ) in vitro [Letter]. Cell Res. 2020;30:269-271. [PMID: 32020029] doi:10.1038/s41422-020-0282-0

2. Gao J, Tian Z, Yang X. Breakthrough: Chloroquine phosphate has shown apparent efficacy in treatment of COVID-19 associated pneumonia in clinical studies. Biosci Trends. 2020;14:72-73. [PMID: 32074550] doi:10.5582/bst.2020.01047

3. U.S. National Library of Medicine. ClinicalTrials.gov. Accessed at https://clinicaltrials.gov/ct2/home on 3 April 2020.
4. Belhadi D, Peiffer-Smadja N, Lescure F-X, et al. A brief review of antiviral drugs evaluated in registered clinical trials for COVID19. Preprint. Posted 28 March 2020. medRxiv. doi:10.1101/ 2020.03.18.20038190

5. Aralen Chloroquine Prescribing Information. Sanofi-Aventis; March 2013. Accessed at www.accessdata.fda.gov/drugsatfda docs/label/2013/006002s043lbl.pdf on 3 April 2020.

6. Plaquenil Hydroxychloroquine Prescribing Information. Concordia Pharmaceuticals; January 2017. Accessed at www.accessdata.fda. gov/drugsatfda_docs/label/2017/009768s037s045s047lbl.pdf on 3 April 2020.

7. Chen J, Ping L, Li L, et al. A pilot study of hydroxychloroquine in treatment of patients with common coronavirus disease-19 (COVID-19). Journal of Zhejiang University (Medical Science). 2020;49. doi:10.3785/j.issn.1008-9292.2020.03.03

8. Chen Z, Hu J, Zhang Z, et al. Efficacy of hydroxychloroquine in patients with COVID-19: results of a randomized clinical trial. Preprint. Posted 10 April 2020. medRxiv. doi:10.1101/ 2020.03.22.20040758

9. Tang W, Cao Z, Han M, et al. Hydroxychloroquine in patients with COVID-19: an open-label, randomized, controlled trial. Preprint. Posted online 14 April 2020. medRxiv. doi:2020.04. 10.20060558

10. Barbosa J, Kaitis D, Freedman R, et al. Clinical outcomes of hydroxychloroquine in hospitalized patients with COVID-19: a quasi-randomized comparative study. NEJM submission ID 2008882. 4 April 2020.

11. Gautret $P$, Lagier JC, Parola $P$, et al. Hydroxychloroquine and azithromycin as a treatment of COVID-19: results of an open-label non-randomized clinical trial. Int J Antimicrob Agents. 2020:105949. [PMID: 32205204] doi:10.1016/j.ijantimicag.2020.105949

12. Mahevas $M$, Tran VT, Roumier $M$, et al. No evidence of clinical efficacy of hydroxychloroquine in patients hospitalized for COVID-19 infection with oxygen requirement: results of a study using routinely collected data to emulate a target trial. Preprint. Posted online 14 April 2020. medRxiv. doi:10.1101/2020.04.10.20060699

13. Chorin E, Dai M, Shulman E, et al. The QT interval in patients with SARS-CoV-2 infection treated with hydroxychloroquine/ azithromycin. Preprint. Posted 3 April 2020. medRxiv. doi:10.1101/ 2020.04.02.20047050

14. Gautret $P$, Lagier JC, Parola $P$, et al. Clinical and microbiological effect of a combination of hydroxychloroquine and azithromycin in 80 COVID-19 patients with at least a six-day follow up: a pilot observational study. Travel Med Infect Dis. 2020:101663. [PMID: 32289548] doi:10.1016/j.tmaid.2020.101663

15. Molina JM, Delaugerre C, Le Goff J, et al. No evidence of rapid antiviral clearance or clinical benefit with the combination of hydroxychloroquine and azithromycin in patients with severe COVID-19 infection [Letter]. Med Mal Infect. 2020. [PMID: 32240719] doi:10.1016/j.medmal.2020.03.006

16. Lowe D. The latest hydroxychloroquine data, as of April 11. In the Pipeline blog. 11 April 2020. Accessed at https:// blogs.sciencemag.org/pipeline/archives/2020/04/11/the-latesthydroxychloroquine-data-as-of-april-11 on 12 April 2020.

17. Harris AM, Hicks LA, Qaseem A; High Value Care Task Force of the American College of Physicians and for the Centers for Disease Control and Prevention. Appropriate antibiotic use for acute respiratory tract infection in adults: advice for high-value care from the American College of Physicians and the Centers for Disease Control and Prevention. Ann Intern Med. 2016;164:425434. [PMID: 26785402] doi:10.7326/M15-1840

18. Petrisor B, Bhandari M. The hierarchy of evidence: levels and grades of recommendation. Indian J Orthop. 2007;41:11-15. [PMID: 21124676] doi:10.4103/0019-5413.30519 
Current Author Addresses: Dr. Qaseem: American College of Physicians, 190. N Independence Mall West, Philadelphia, PA 19106.

Dr. Yost: 800 Lancaster Avenue, Villanova, PA 19085.

Dr. Etxeandia-lkobaltzeta: 1, Santa Margarita Hospital Street, Ground Floor 2, Office 1, Room 2, 20303 Irun, Gipuzkoa, Spain.

Dr. Miller: Penn Medicine Radnor, 250 King of Prussia Road, Radnor, PA 19087.

Dr. Abraham: 123 Summer Street, Suite 370, North Worcester, MA01608.

Dr. Obley: 3030 SW Moody, Suite 250, Portland, OR 97201.

Dr. Forciea: 3615 Chestnut Street, Philadelphia, PA 19104.

Dr. Jokela: 1405 West Park, \#207, Champaign, IL 61801.

Dr. Humphrey: 3710 SW U.S. Veterans Hospital Road, Portland, OR 97201.

Author Contributions: Conception and design: I. EtxeandiaIkobaltzeta, J.A. Jokela, M. Marcucci, A. Obley, A. Qaseem, J. Yost. Analysis and interpretation of the data: L.L. Humphrey, J.A. Jokela, M.C. Miller, A. Qaseem, J. Yost.

Drafting of the article: G.M. Abraham, I. Etxeandia-Ikobaltzeta, J.A. Jokela, A. Qaseem, J. Yost.

Critical revision for important intellectual content: G.M. Abraham, E.A. Akl, R. Andrews, R.M. Centor, I. EtxeandiaIkobaltzeta, M.A. Forciea, L.L. Humphrey, J.A. Jokela, D. Kansagara, M. Marcucci, A. Obley, A. Qaseem, J. Yost.

Final approval of the article: G.M. Abraham, E.A. Akl, R. Andrews, T.A. Bledsoe, R.M. Centor, I. Etxeandia-lkobaltzeta, M.A. Forciea, R.A. Haeme, L.L. Humphrey, J.A. Jokela, D. Kansagara, M. Marcucci, M.C. Miller, A. Obley, A. Qaseem, J. Yost.

Statistical expertise: A. Qaseem.

Administrative, technical, or logistic support: A. Qaseem.

\section{Appendix: Practice Points Development Process}

The Scientific Medical Policy Committee (SMPC), in collaboration with staff from ACP's Department of Clinical
Policy, developed these Practice Points based on a rapid systematic evidence review conducted by the University of Connecticut Health Outcomes, Policy, and Evidence Synthesis Group. The SMPC comprises 11 internal medicine physicians representing various clinical areas of expertise and 1 public (nonclinician) member and includes members with expertise in epidemiology, healthy policy, and evidence synthesis. In addition to contributing clinical, scientific, and methodological expertise, Clinical Policy staff provided administrative support and liaised among the SMPC, evidence review funding entity and evidence team, and the journal. Clinical Policy staff and the SMPC reviewed and prioritized potential topic suggestions from ACP members, SMPC members, and ACP governance. A committee subgroup, including the chair of SMPC, worked with staff to draft the key questions and lead the development of the Practice Points. Clinical Policy staff worked with the subgroup and the evidence review team to refine the key question(s) and determine appropriate evidence synthesis methods for each key question. Via conference calls and e-mail, Clinical Policy staff worked with the committee subgroup to draft the Practice Points based on the results of the rapid systematic evidence review. The full SMPC reviewed and approved the final Practice Points. Before publication, ACP's Executive Committee of the Board of Regents also reviewed and approved the Practice Points on behalf of the ACP Board of Regents. The evidence review will be continually updated by the evidence review team. ACP will update the Practice Points based on the evidence review using the same process as for Version 1 (described above). 